\title{
Urban Expansion and Green Urbanism in an Amazonian Metropolis: The Production of Urbanized Nature in the Metropolitan Region of Belem
}

\author{
Tiago Veloso dos Santos \\ Geography Department, Federal Institute of Education, Science and Technology of Pará, Belém, Brazil \\ Email: tiago.veloso@ifpa.edu.br
}

How to cite this paper: dos Santos, T. V. (2020). Urban Expansion and Green Urbanism in an Amazonian Metropolis: The Production of Urbanized Nature in the Metropolitan Region of Belem. Current Urban Studies, 8, 623-644. https://doi.org/10.4236/cus.2020.84034

Received: October 23, 2020

Accepted: December 14, 2020

Published: December 17, 2020

Copyright $\odot 2020$ by author(s) and Scientific Research Publishing Inc. This work is licensed under the Creative Commons Attribution-NonCommercial International License (CC BY-NC 4.0). http://creativecommons.org/licenses/by-nc/4.0/ (c) (i) (\$) Open Access

\begin{abstract}
In the recent dynamics of the production of the metropolitan space in Belem, there was a trend of continuous dispersion of the urban fabric of its Metropolitan Region, characterized by two temporally distinct processes in the production of the urban and environmental landscape. On the one hand, a progressive loss of vegetation covers in the central neighborhoods and in the municipalities that make up the metropolitan region, due to the unequal forms of production of the urban space. On the other hand, a recent attempt makes up for urban and environmental policies via the creation of a set of conservation units in the metropolitan space by different political spheres. Based on this observation and using the concept of urbanized nature, this paper presents evidence of the implementation of a set of policies and practices that enabled the production of a new urban spatiality, this time operating on a metropolitan scale and using the environmental issue as a way of structuring the metropolitan area of Belém around a particular type of green urbanism. In terms of research methods, we opted for a comparative methodology between different historical and geographic periods of urban formation, with an emphasis on documentary checking and analysis of satellite images and historical iconography.
\end{abstract}

\section{Keywords}

Amazon, Urbanization, Urbanized Nature, Green Urbanism, Metropolitan Region of Belem

\section{Introduction}

The intensification of the space metropolization process in Brazil has shown a 
general predisposition to express itself in an increasingly visible way in the various regions of the national territory. The configuration of a mostly urban and particularly metropolitan Brazil at the beginning of the $21^{\text {st }}$ century can be seen through the set of statistics ${ }^{1}$ provided by institutions such as the Brazilian Institute of Geography and Statistics (IBGE). More than quantitative recognition, such evidence is an expression of a trend that is materialized in the territory and distributed on a regional scale, albeit in a heterogeneous manner.

One of the regional peculiarities observed in the dissemination of this process is in the existence of a complex scenario of society and territory urbanization that is expressed on a regional level in several ways, so it is possible to affirm that there is a tendency towards metropolization (Lencioni, 2008; Lencioni, Vidal-Koppman, Hidalgo, \& Pereira, 2011), which spreads across the territory extensively (Monte-Mór, 2003).

In the Brazilian Amazon, this reality points to the fact that significant portions of the region have followed the slopes of urbanization in recent decades and, more recently, of metropolization, resulting in a regional dynamic with the constitution of a diversity of urban forms and very expressive metropolitan agglomerations among them, such as the one built around the city of Belem.

In this sense, the Metropolitan Region of Belem (RMB) is the spatial institutionalization of the trend towards metropolization that has been present since the 1960s, being an urban expression of the development of regional integration processes that have been carried out in the Amazon region since then. The constitution of a metropolitan agglomeration in a city that has always been an important regional urban center has modified its intra-urban structure and can be understood within some particularities that are more evident in recent decades. The continual spread of the urban area of the metropolis stands out, which has been characterized by the progressive expansion of its urban and institutional network over the last three decades. This spread is materialized both in the expansion of the number of municipalities that make up the metropolitan region and a dispersion of the urban fabric marked by a contradictory coexistence process with the elements that constitute the built environmental landscape, characterizing an extensiveness of regional urbanization, according to Monte-Mór (2003).

On the one hand, there is a progressive loss of vegetation cover in the neighborhoods of Belem and the municipalities that make up the metropolitan region. This loss has been the object of detail and concern of an urban, environmental and symbolic character, since the historical constitution of the city of Belem has a lot to do with the construction of an identity around the natural elements that make up its urbanization in a kind of "urbanized nature", in a regional perspective.

On the other hand, the strengthening of an urban sustainability agenda with

${ }^{1}$ Urbanization data in Brazil and in the region: IBGE presents $84.6 \%$ as the official urbanization rate in Brazil from the 2010 Demographic Census. Furthermore, considering only the 12 (twelve) largest metropolitan regions in the country, the same institute identifies approximately 40 million people living in these spaces, corresponding to an approximate percentage of $20 \%$ of the Brazilian population (IBGE, 2010). 
the implementation of environmental policies and measures in state and municipal government spheres has caused significant impacts on the recent conformation of the metropolitan structure of Belem, to the point of showing an attempt of compensating for the loss trend previously described.

Therefore, it is observed in the MRB that its metropolitan space has undergone a restructuring dynamic that involves the territorial expansion of its urban network with effects in the political-administrative structures that caused an intensification of long-lasting processes with clear impacts on the intra-urban structure, which includes the production of green areas and environmental zones.

Throughout this text, three historical periods of constitution of the process geography that gave rise to the urban and environmental configuration of the current metropolitan Belem are presented, considered as references of the changes in the Amazon region after the national integration processes. In the three periods, the materialization in the urban landscape of a produced imaginary of "urbanized nature" (Angelo \& Bastos, 2020) is a variable of urbanization in the metropolis. In this case, the imaginary around the "green" is a direct product of an idea of nature that accompanies urbanization processes at different times (Angelo \& Bastos, 2020).

We begin with a presentation of the urban-environmental formation constituted in the first half of the $20^{\text {th }}$ century. The first period, which goes from the 1900 s to the 1950s, is associated with transformations derived from the rubber extraction cycle that promoted the image of the city represented by an environmental identity of urbanized nature, Cidade das Mangueiras ("Mango Tree City").

The second period deals with the unfolding of urban transformations since the 1960s, especially the effects of the induction of the metropolization of the city space and its surroundings, which caused negative impacts on the urban and environmental structure that existed until then. These transformations have indicated a progressive and worrying trend of loss of vegetation cover in the city of Belem and in the municipalities that made up its metropolitan region over thirty years, showing a strict association between metropolization and cover loss.

In a third moment, the trend verified in more recent decades is presented particularly with the consolidated metropolitan configuration of Belem taking very different forms from those seen until the 1960s, which caused a change in the environmental policy guidelines in the urban space. These transformations can be recognized through the analysis of a set of policies and practices that are instrumentalized to build, model and discipline a specific spatiality in the urban space of MRB and that result in the adoption of a set of measures whose material expression is the creation of metropolitan parks that reconfigure its morphology.

In methodological terms, the development of these interpretations around the results of this text adopted a research approach that started from the recognition of an urban genealogy in Belem along with the understanding of the political 
economy of the city, using initially a bibliographical survey on the landscape and environmental aspects of the highlighted periods. This survey considered for the purposes of analysis the normative and institutional design that constitutes the foundation for the establishment of an urbanized nature in the metropolitan space, in addition to the literature on the subject.

In terms of document analysis, it is important to understand that the collection of documents was divided into two distinct moments that correspond to the periods analyzed: the first one was the set of reports from the Municipal Council of Belem that guided urban planning in the first half of the $20^{\text {th }}$ century. The second one was a very different institutionality, resulting from a much more complex urban space since the 1990s, in which there were regulations of the bodies responsible for the creation and management of the various Conservation Units (UC) that exist in the MRB, such as the State Secretariat for the Environment of the Government of Pará (SEMA), the Municipal Secretariat for the Environment of Belem (SEMMA) and the Municipal Secretariat for the Environment of Ananindeua (SEMA). The regulations and legislation at the municipal and state levels were elements that consolidated the exposed interpretation. The document collection also enabled them to be used for the purpose of visualizing the characteristics we are dealing with, an iconography for each period described.

Finally, satellite images were used throughout the process to build a thematic cartography that systematized the processes of altering the morphology of land use in the metropolitan space, as stated along this work. The satellite images used for cartography involved data made available since the 1980s and helped to visualize the changes observed in the Metropolitan Region of Belem.

This set of information allowed the identification of a new design of the urban and environmental structure of the metropolis and that represents the understanding of the research object around the constitution of a new urbanized nature, now on a metropolitan scale.

\section{The Formation of the "Mango Tree City": Urban Growth and Aesthetic Urbanism}

In the early twentieth century, Belem experienced a process of modernization brought about by surplus capital from latex exports². Sarges (2002) points out that "urban development was accelerated with the fall of the Empire and the establishment of the Republic, as the new regime gave greater autonomy in the use of taxes and allowed the State to have a greater participation in export income" (Sarges, 2002: p. 78).

In addition, the city became the gateway for immigrants, travelers and busi-

${ }^{2}$ The Rubber cycle corresponded to the period between 1870-1912, in which the demand for a product, the rubber latex, met the growing needs of the international market of the growing automobile industry. The capital volume injected into the Amazon region in this period was on such a scale that it caused a massive displacement of workforce to extract latex within the forest. This capital was also used by the economic and political elites at the time to remodel the main cities (Belém and Manaus) based on European urban inspiration, notably the French "Belle Époque" (Sarges, 2002). 
nessmen attracted by the economic expansion and official propaganda that sought to stimulate the arrival of workforce, due to its geographical position as the regional port closest to Europe.

This movement provoked a true urban metamorphosis in Belem, with the governors Augusto Montenegro (1901-1908) and the intendente (equivalent to a mayor) Antônio Lemos (1897-1911), the main political leader at the time, who remained as the head of the city administration for fourteen years, remodeling its urbanized space (Matos, 2016).

The reflexes of these structural changes in the establishment of an urban project in Belem were clear: a series of beautification projects and the installation of public service networks in the city, which had as an inspiring urban ideal the Paris remodeled by the Haussmann reform ${ }^{3}$. Therefore, more than a simple modernization of the infrastructure, the urban design at the time idealized a "beautified" city, and this beautification included its hygiene enhancement and valuing of the "natural environment".

One of the effects of this urbanism was the projection of wide, tree-lined streets, squares and green open spaces, which followed the general instruction of the Municipal Council, that there was a need to create healthy and clean places. In the official reports, the idea of projecting a city associated with standards of scenic beauty and aesthetic hygiene is identified.

Afforestation was part of the urban project, since the preservation of nature indicated a healthy urban life within the standards of beautification, in addition to softening the heat in the tropical city. The intendente was proud to have had mango trees planted on the streets of the city, characterizing Belem as "(...) one of the Brazilian cities most widely endowed with trees. Numerous streets are lined with trees and our avenues boast beautiful rows of opulent representatives of the lush equatorial flora" (Belém, 1905: p. 271).

The figures (Figure 1) demonstrate one of the main urban expressions of the period, the afforestation of an aesthetic nature in the central area of the city of Belem:

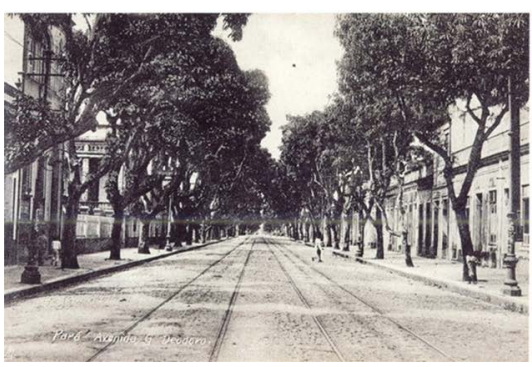

Source: Belém (2000).

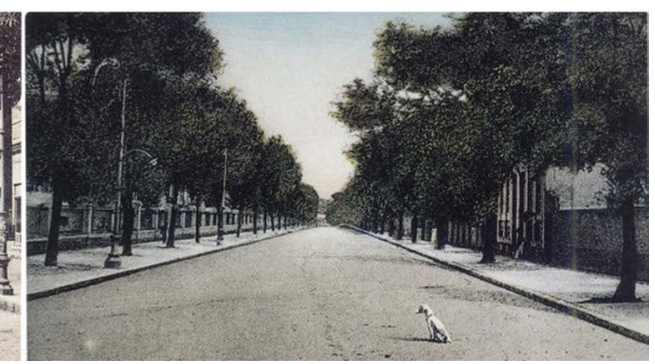

Figure 1. Naturalistic urbanism: mango trees in the central streets of Belem.

${ }^{3}$ Paris urban reform promoted by Georges-Eugène Haussmann, mayor of the department of the Seine between 1852 and 1870. Haussmann concentrated urban improvements in order to promote improvements in military maneuvers, as well as in the circulation and hygiene of Paris. To this end, numerous small and narrow streets from the medieval period were demolished and boulevards that organized urban space were created, as well as gardens and parks (Azevedo, 2016). 
For this reason, the various works and interventions carried out in the period of economic expansion provided by the rubber cycle and idealized by Antônio Lemos, especially the improvements of squares and afforestation in the central area, make possible a certain image of Belem, which will remain throughout the $20^{\text {th }}$ century, the Cidade das Mangueiras ("Mango Tree City"). An image that was built less from the original characteristics of the site and urban physiography and much more from the materialization of an "urbanized nature" that, according to Angelo \& Bastos (2020), is both a product and a variable of urbanization:

"To examine the origins and socio-spatial effects of the idea of green as a 'good' in cities, I argue that, instead of being a reactive element to 'cities' in itself, green is the product of a recent idea about nature that has been treated as an indirect or moral good. I call this urbanized nature, the result of urbanization processes, but also a variable of them. I also argue that this is a particular type of moral belief, a 'social imaginary'” (Angelo \& Bastos, 2020: p. 12).

An example of this urbanized nature as a choice deals with the species of mango trees to compose this aesthetic and scenic urbanism, which not only obeyed a scenic choice, but was the subject of meticulous choice in the composition of urbanism at the time. Species such as almond and samauma tree have been suggested, but not considered ideal. The mango tree overcame them for having "several qualities: it develops quickly, has height and sheds branches with regularity", according to the intendance. In addition, "it presents dense and constantly renewed foliage, ideal for mitigating the effects of the tropical climate".

A less well-known aspect of this option is that it was motivated by the brutal levels of poverty of the lower classes in Belem, even at the height of the rubber cycle's opulence. And that made the fruit of the mango tree-the mango-an important element in the composition of the diet of these classes. Recent research $^{4}$ (Tavares, 2018) indicates that this was one of Antônio Lemos' objectives, which generated tensions from the point of view of "civilized" norms at the time. Stoning of trees in search of fruit became common, a behavior that started to be punished according to the norms of the time, since it was contrary to the "civilizing standards" that that type of urbanism aimed to achieve.

In addition to the afforestation of the streets and avenues, important spaces were built for green areas in the expanding city, in the spirit of the time of landscape beautification and aesthetic and natural hygienization of the urban environment, which remain important spaces in urban dynamics to the present day, especially the Rodrigues Alves Botanical garden and the Emilio Goeldi $\mathrm{Mu}$ seum's Zoobotanical Park.

${ }^{4}$ Tavares, M. G. C. Patrimônio e cidade: uma leitura geográfica da cidade de Belém do Pará. Geografar: Revista Eletrônica do Programa de Pós-Graduação em Geografia da UFPR, v. 13, p. 162-180, 2018 . 
Rodrigues Alves Botanical garden was founded in 1883, in a place that was then an expansion area ${ }^{5}$ of the city. Founded in the midst of the cultural effervescence favored by rubber extraction, it was designed to be a kind of environmental reserve and was also one of the measures to ensure the city's beautification.

The Emilio Goeldi Museum was conceived as a space dedicated to scientific purposes. Designed in the context of European naturalists' expeditions to the Amazon, the museum was founded with the aim of promoting studies on the region. The first initiative in 1889 ends with its closure, due to the precariousness of the facilities and in the turbulent context of the end of the imperial regime and the beginning of the Republic. In 1893, Governor Lauro Sodré invited the Swiss naturalist Emilio Goeldi to reopen it, now as a Zoobotanical Park, and turn it into a research center. Technicians and scientists were hired to compose the institution's staff. Goeldi gave the Museum a defined profile, with measures that included the transfer to a new headquarters, with the formation of a "scientific colony" and the creation of a Zoological Garden and a Botanical Garden. Politically, the museum was important in building the identity of the regional elite. According to Goeldi himself (Sanjad, 2005) the space for the museum was built as if it were an instruction school for works of Amazonian nature. Therefore, the preservationist function made the Emilio Goeldi Museum the reference model for parks to the present day, in addition to serving the function of contemplative leisure, dedicated to the studies of fauna and flora, the man of the Amazon and his physical environment.

The implantation of these first urban parks valued the remainder of the Amazon rainforest and the use of water in projects for green spaces. Although the hygienist aesthetic interventionist urbanism found its zenith in the 1910s, it got stuck in the memories of the local society and the urban and environmental heritage of Belem.

The decline of the Rubber economy, starting in 1912, caused a prolonged economic decay until the end of the 1950s, and this subsequent period turned out to be poor in urban achievements, having as its main background a scenario of stagnation that had little repercussion in the urban form and investments in the structure of Belem. This scenario will only be surpassed by urban interventions related to regional integration projects that start to have indirect effects in Belem from the 1960s, contributing slowly and steadily to its transformation into a metropolis and with significant repercussions on its intra-urban structure and environmental morphology.

\footnotetext{
${ }^{5}$ Currently located on Almirante Barroso Avenue, in one of the central neighborhoods of the city, Bosque Rodrigues Alves was transformed into the Zoobotanical Garden of the Amazon, being one of the main postcards of the city. It maintains the original area of 15 hectares, with significant forest preservation. The space is managed by the Municipality of Belém and receives, on average, 20,000 visitors per month. It houses more than 10,000 trees, distributed in more than 300 species. Out of the 15 hectares, more than $80 \%$ are composed of green areas. Bosque is home to 435 animals of 29 species that live in captivity and 29 in freedom or semi-freedom (Belém, 2005).
} 


\section{The Formation of Metropolitan Belém and the Progressive Loss of the "Mango Tree City"}

The production of the metropolitan space in Belem from the second half of the twentieth century has particularities arising from its formation as an urban reference in the regional scenario. The historical-geographical context recognizes the history of the metropolitan formation of Belem, associated with changes in the region established since the 1960s, when the city was still confined to an area relatively close to its founding place. The periodization presented by Moreira (1989) on the urban growth of Belem until the 1960s reports that:

In principle, the city expanded following the fluvial border, and then went inland and continentalized itself, defining the first three phases of its growth: the riverside (from the foundation of the city in 1616 until the middle of the $18^{\text {th }}$ century); penetration or interiorization (from the mid- $18^{\text {th }}$ century to the mid- $19^{\text {th }}$ century); and continentalization (from the mid-19 ${ }^{\text {th }}$ century onwards) (Moreira, 1989: p. 52).

According to Trindade Júnior (1998), only in a more recent period is it possible to affirm the characterization of a fourth phase of urban expansion, marked by the dynamics of metropolization, which presupposes the significant advance of the urban network in relation to the period and the previous phases:

We would add to this periodization by Moreira (1989), another phase, that of metropolization, which begins in the sixties and is consolidated in the following decades and which presupposes the incorporation of cities and towns close to Belem, defining a unique urban fabric, despite of being fragmented (Trindade Júnior, 1998: p. 3).

In this case, it is understood that the city of Belem had its moment of expansion towards the complex metropolitan formation in the context of alteration of the regional circulation networks, particularly with the construction of the Belem-Brasília highway, the first major highway axis in the Amazon Basin (Vicentini, 2004). The changes in the role of the region also had repercussions on the production of the urban space of Belem, which was physically limited until the 1960s, as noted in Figure 2.

Such transformations caused significant changes in the intra-urban space of Belem, the most important one being the continuous spreading of the urban fabric towards the expansion areas considered peripheral in relation to the oldest center until then, and also towards the nearby municipalities.

One of the most impacting effects on the urban environment of this progressive transformation is the continuous loss of vegetation cover with the advance of the metropolization process, since in the following decades the creation of the Metropolitan Region of Belem about $201 \mathrm{~km}^{2}$ or $17 \%$ of its coverage forestry is lost (Imazon, 2007), with most of the remaining native forest concentrated in the islands that make up the municipal territory and in restricted areas (military sectors, public teaching and research institutions):

In the 1980s, the green area of the [Metropolitan Region of] Belem represented about $50 \%$ of its territory $\left(588 \mathrm{~km}^{2}\right)$, in the $1990 \mathrm{~s}$, specifically considering the 


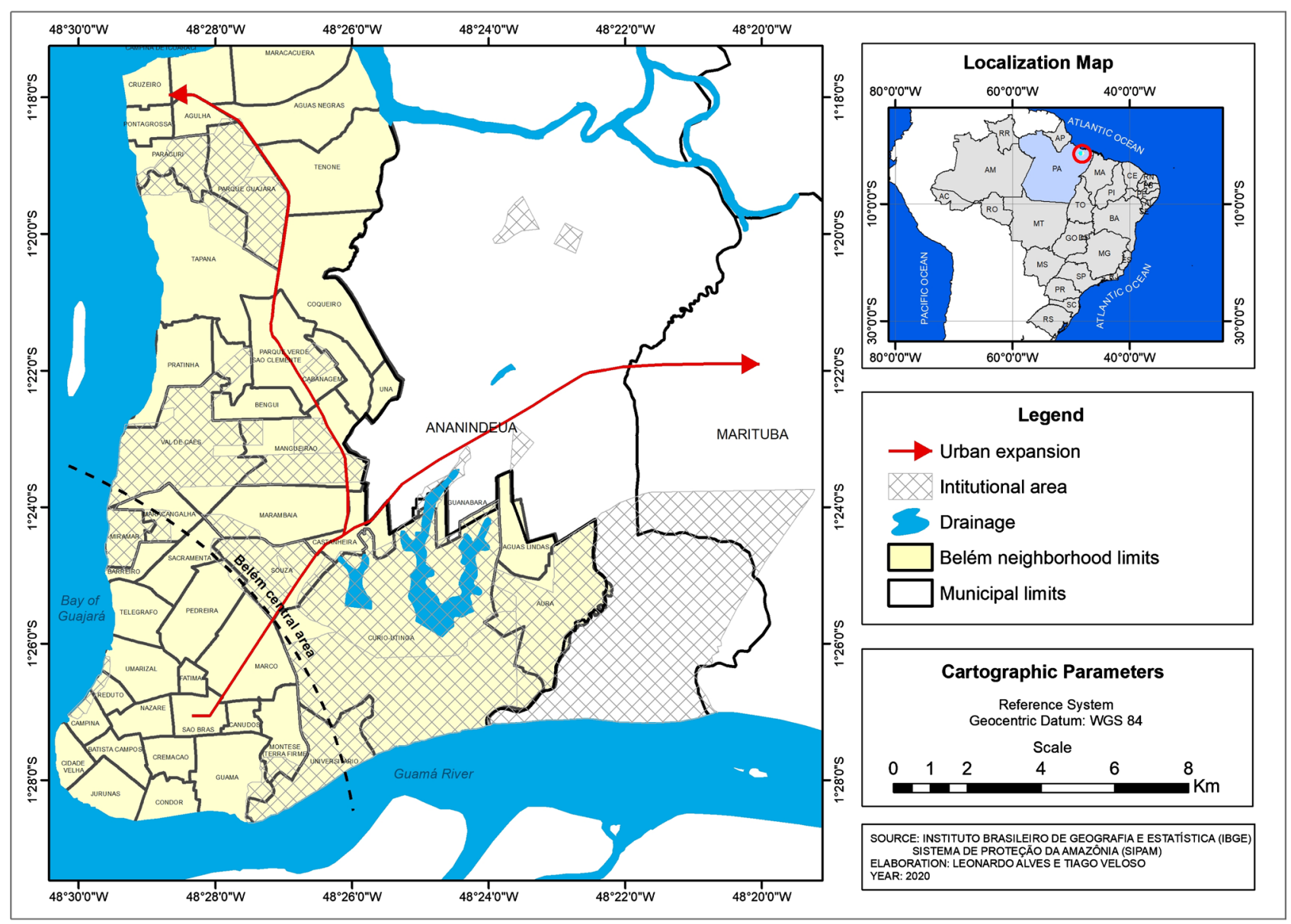

Source: Organized by the author (2017).

Figure 2. Belem: trends of urban expansion in 1960.

year 1994 this area was reduced to $37 \%\left(434 \mathrm{~km}^{2}\right)$ and in the early 2000 s, in 2001 , it was further reduced to around $33 \%\left(388 \mathrm{~km}^{2}\right)$. In just under two decades, the average annual loss of vegetation cover in the metropolitan region was $1.12 \%$. The municipalities that suffered the greatest deforestation were Santa Bárbara $\left(57 \mathrm{~km}^{2}\right)$, Benevides $\left(41 \mathrm{~km}^{2}\right)$ and Belem (40 km²) (Imazon, 2007: p. 11).

The advance of urbanization projects in the 1980s and 1990s, particularly in Belem, was an element that led to the greatest loss of vegetation cover in the city, especially in the central neighborhoods, where the main mango tree areas constituted in the first decades of the century are located, as previously demonstrated.

As examples, the central districts of the municipality of Belem ${ }^{6}$, DABEN (Belem District), DASAC (Sacramenta District) and DAGUA (Guamá District),

${ }^{6} \mathrm{DABEL}$ is composed entirely of the neighborhoods of Campina, Reduto and Nazaré and partially the neighborhoods of Batista Campos, Canudos, Cidade Velha, Cremation, Jurunas, Marco, São Brás and Umarizal. It has a population of 144,948 inhabitants. DAGUA is formed by Terra Firme and Condor neighborhoods, as well as part of Jurunas, Batista Campos, Cidade Velha, Guamá, Cremation, Canudos, São Brás, Marco and Curió-Utinga neighborhoods. It has a population of 342,742 inhabitants. DASAC is formed by the neighborhoods of Sacramenta, Maracangalha, Miramar, Telegrafo, Pedreira, Fátima and part of the neighborhoods of Marambaia, Marco, Umarizal and São Brás. It has a population of 256,641 inhabitants (IBGE, 2010). 
which correspond to almost all of the central areas of the city, currently maintain only about $16.9 \%$ (DASAC), 29.4\% (DABEN) and 18.2\% (DAGUA) of green area in relation to the total area of the districts, respectively, as shown in Figure 3.

For Rodrigues and Luz (2007), such a significant loss of green areas downtown has to do with the development of infrastructure projects to expand the urban network, such as drainage programs for river basins throughout the 1990s. For the authors:

In the 1990s, the macro-drainage carried out with resources from the IDB (Inter-American Development Bank) and the counterpart of the state government, promoted major changes in the DASAC area (Sacramenta Administrative District). (...) The purpose of the works was to control flooding and to treat the sewage (...) by draining and channeling the basin, which led to the grounding, paving and urbanization of extensive areas. In 2004, the resulting changes show
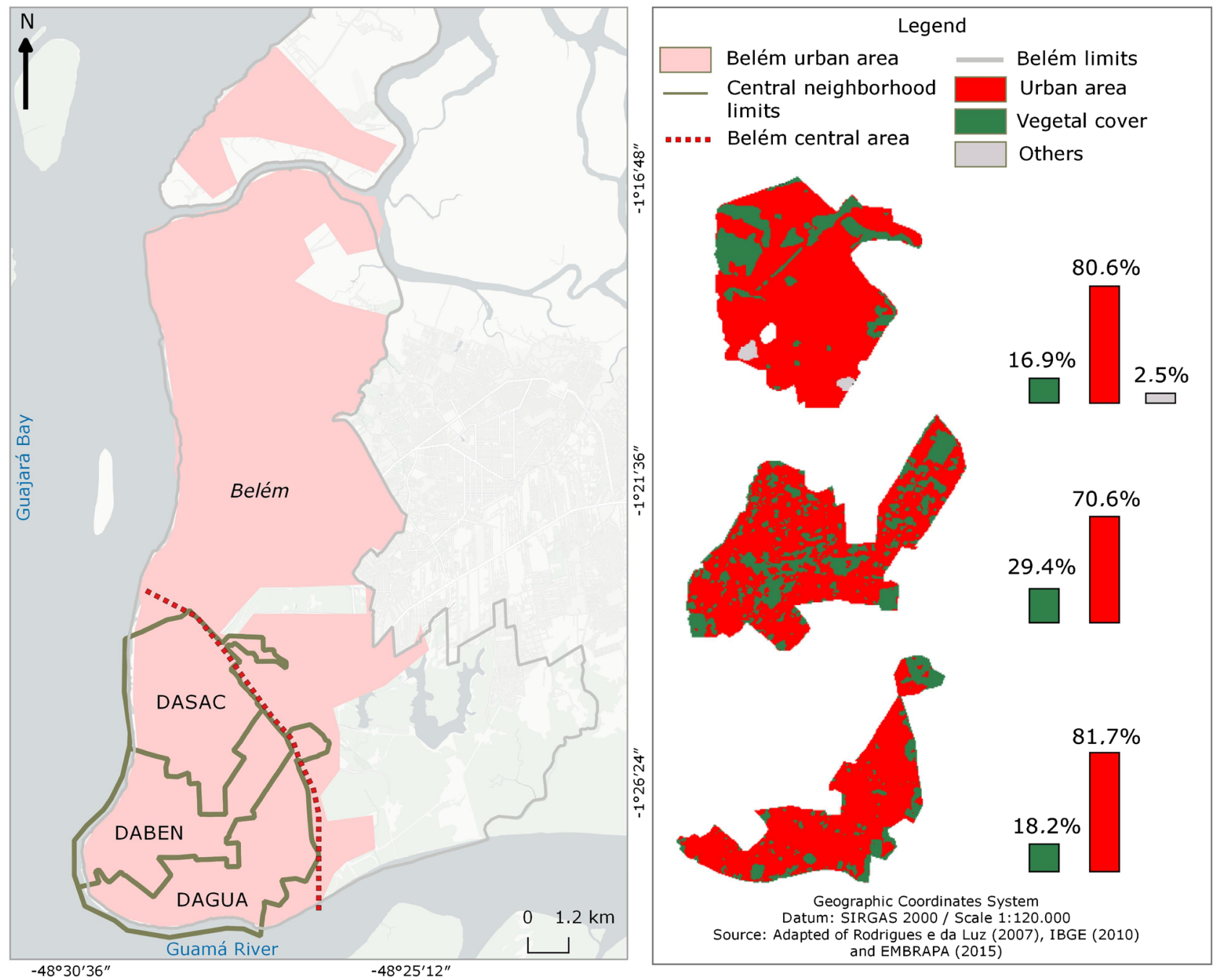

Source: Organized by the author (2020).

Figure 3. Belem: urban area and vegetation cover in the central districts. 
an increase of $85 \%$ in the no-vegetation area, the low density dropped to $10 \%$, forming isolated patches in the urban matrix. The medium and high density dropped to $2 \%$, and form isolated fragments in the district (Rodrigues \& Luz, 2007: p. 1068).

However, this continuous loss of vegetation cover in the metropolis is not exclusive to its core municipality-Belem-since this inclination also occurs among the other municipalities that make up the metropolitan space, since the progressive decrease of green areas is temporarily associated with the expansion of metropolization.

Furthermore, a broader metropolitan space in Belem has been constituted since the 1970s, which in a short period of time surpassed the restricted limits that the city still maintained until the 1960s. This metropolitan formation is characterized by the advance of the urban network of Belem towards its most immediate expansion area in the peripheral neighborhoods, as well as for the adjacent municipalities. This advance has caused major changes of urbanized nature in the intra-urban structure and in the environmental landscape.

Ananindeua is taken as an example of this movement ${ }^{7}$, the second most important municipality in demographic and economic terms among the seven constituent municipalities of the Metropolitan Region of Belem.

The expressive growth of the population of the municipality of Ananindeua was due to the intensification of the process of metropolization of Belem, which was dispersed continuously towards one of the axes of expansion of the metropolis, the BR-316 highway, which crosses the municipality of Ananindeua (as can see above on the text, in Figure 2).

Considering this urban dynamic, the construction of housing estates began for the purpose of settling residential populations that were continually being evicted from the central neighborhoods of Belem, partly due to the increase in the value of urban land. Among them, the largest one, Cidade Nova Housing Complex, was based on housing programs under the responsibility of the Housing Company of the State of Pará (COHAB), as a sort of ordering policy for the immediate periphery of the metropolis (Rodrigues, 1998). On the margins of this process, areas of spontaneous occupations emerged, located close to housing estates. As officially observed by the municipality itself:

The municipality of Ananindeua, which from 1973 onwards forms the Metropolitan Region of Belem, has undergone a vigorous urbanization process. As a result of the implantation of the 600 initial houses of the Cidade Nova I Housing Complex, in 1977, a nucleus was formed in that region that would tend to consolidate and expand with new areas of this housing development (...) (Ananindeua, 2006: p. 84).

The continuous spread of the urban network was not only responsible for the

${ }^{7}$ Ananindeua, in addition to being the second largest municipality in the Metropolitan Region of Belém, is also the second most populous municipality in the state of Pará and the third in the Amazon region. Its population is estimated at 471,744 inhabitants (IBGE, 2010). 
forms of occupation of the metropolitan fabric's expansion areas. There was also a progressive loss of vegetation cover, with a significant alteration of the landscape, mainly with the replacement of an area with rural characteristics, constituted in its majority by sites that conserved vegetated areas, riparian forests and the presence of the practice of agriculture in the cultivable lands.

The observation of the evolution of vegetation cover in the municipality of Ananindeua (Figure 4), particularly analyzing the area of Cidade Nova Housing Complex from 1984 to 2008 (Andrade \& Tozi, 2019), demonstrates the significant loss of about $85.53 \%$ of a green area of 5,746,624 $\mathrm{m}^{2}$ which comprises the entire limit area of the complex, the main residential housing estate in the municipality.

The marked metropolization process caused an almost irreversible trend of loss of vegetation cover in the mainland area of the municipality, which reached $78.03 \%$ as of 1986 , according to the satellite images ${ }^{8}$.

In this case, considering that the municipality has been part of the MRB since
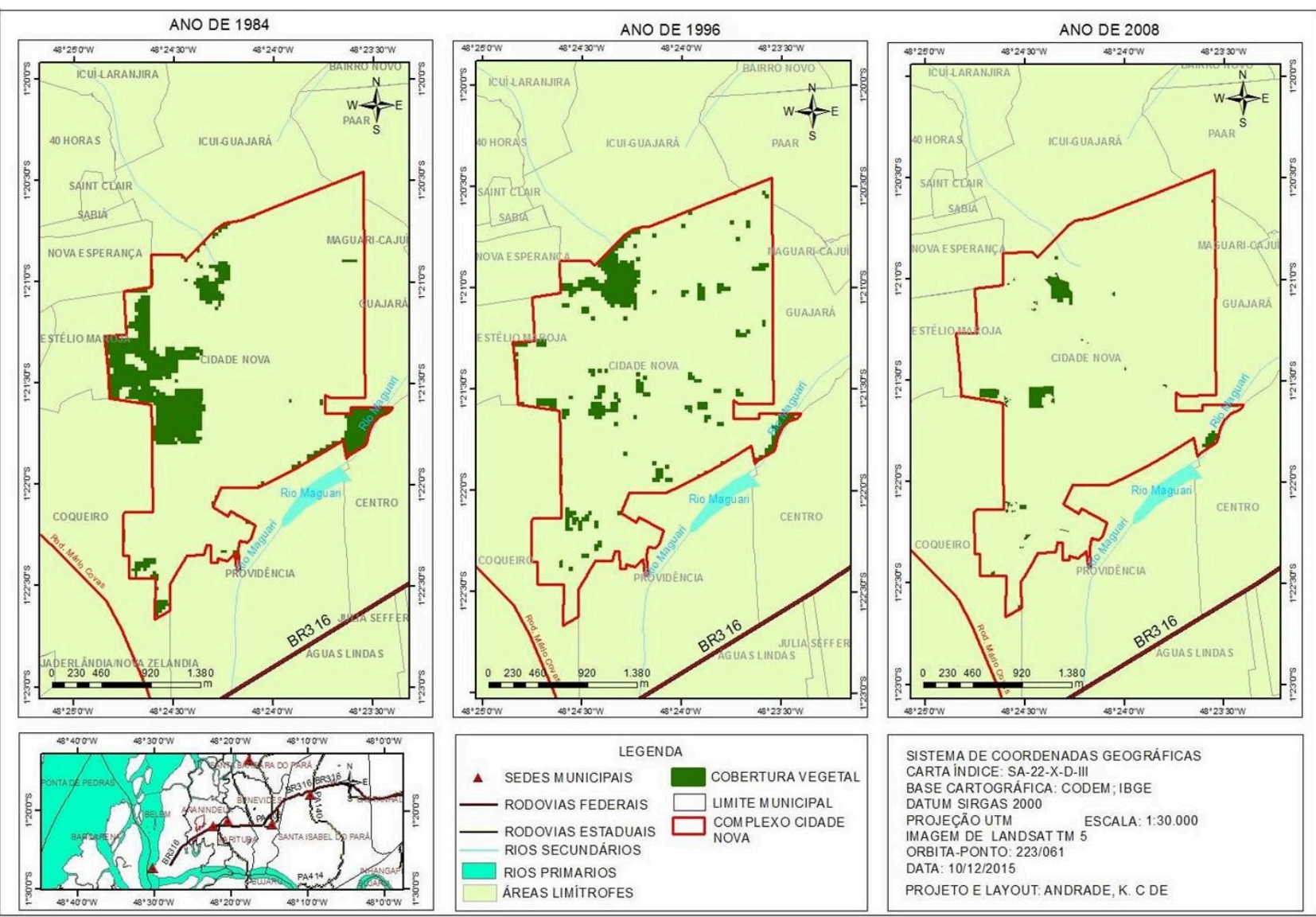

Source: Andrade \&Tozi (2019).

Figure 4. Ananindeua: evolution of vegetation cover in Conjunto Cidade Nova.

${ }^{8}$ After obtaining, processing and analyzing the years in terms of the vegetation cover in the Cidade Nova Housing Complex, the spatial coverage of the aforementioned 223/061 orbit-point scenes was observed, comprising the entire studied area, and a decrease of the green area was identified during these three periods analyzed comparatively. Such decrease is only explained in the light of the occupation process of the complex (Andrade \&Tozi, 2019). 
the 1970s, the phenomenon of continuous loss of its green areas with the intensification of urbanization reinforces the process previously stated for the metropolitan space. In addition, there is evidence that such a process of continuous, progressive and systematic loss of the green areas in the MRB is not restricted only to its oldest municipalities, on the contrary, it is spread across most cities, although differing to a greater or lesser extent. Between 1986 and 2001, for example, the total deforested metropolitan area was $201 \mathrm{~km}^{2}$. The municipalities that suffered the greatest deforestation were Santa Bárbara do Pará $\left(57 \mathrm{~km}^{2}\right)$, Benevides $\left(41 \mathrm{~km}^{2}\right)$ and Belem itself $\left(40 \mathrm{~km}^{2}\right)$.

\section{Metropolitan Dispersion, Urbanized Nature and Green Urbanism in the "Metropolis of the Parks"}

In a more recent period, from the 1990s and under the perspective of the production of an increasingly dispersed urban space, the construction of the urban landscape of the Metropolitan Region of Belém has been marked by the implementation of an environmental policy via the creation of ecological-environmental preservation areas at state and municipal scales.

From a general point of view, this trend cannot be disconnected from structural processes at a global level, such as, for example, the valuing of urban development approaches related to the insertion of environmental elements in urban planning and management. In this case, it is clear that there is a context of diffusion of ideas and knowledge, which at a given moment are appropriated by relevant social agents in the management of urban policies.

The impacts of implementing this environmental agenda in the MRB in recent decades, and in particular, the adoption of these policies in the metropolitan space, provoke remodeling in view of the processes of loss of green cover, urban identity and urbanized nature, as analyzed in the previous item.

For Cavalcanti (2008), "the diffusion of innovations in the urban agenda has had a subtle and sometimes explicit impact on the formulation of urban policies in Brazilian cities. This aspect is of utmost importance to be investigated and to increase knowledge about the process of how policies are formulated; who are the main actors involved and how decisions to implement urban programs are made" (Cavalcanti, 2008: p. 24).

At the same time, it cannot be disregarded that the establishment of an environmental policy on a national scale is an element that greatly contributed to the institutionalization practices of urban-environmental spaces linked to the idea of nature preservation and conservation of landscape elements, propositions of more "sustainable" environmental urban planning and management, because in the context of implementation of a particular development approach in the urban space, it is necessary to create or readjust a set of elements that enable the application of policies and have administrative and symbolic legitimacy. These elements aim to create an image of actions that are intended to be implanted in such space. This set of elements, system of objects and system of actions takes 
forward spatial practices. According to Santos:

The space is formed by an inseparable, solidary and contradictory set of systems of objects and systems of actions, not considered in isolation, but as the unique framework in which history takes place. [...] Today, the space is a system of increasingly artificial objects, populated by systems of actions equally imbued with artificiality, and increasingly tending towards ends foreign to the place and its inhabitants (Santos, 2004: p. 39).

In this case, a set of decisions, institutions, norms and symbols is considered as the composition of a system of objects and actions, which identifies an approach in conducting the urban development guideline based on the planning instruments of the metropolitan space.

In fact, understanding urbanism as a set of techniques and practices that aim to model urban space and, ultimately, to discipline social practices (Hoffman, 2011) the emergence of a "green urbanism" cannot be associated exclusively with plans and regulatory instruments, but also the adoption of social norms and practices associated with a new built environment and new elements of the landscape.

Thus, unlike the "business as usuap" of recent trends in global urbanism, what we have seen being produced in terms of urban-environmental morphology in the MRB is not associated with aggressive marketing of new green urbanism or urban "sustainability practices" as a space management model. One hypothesis for this to occur is due to the fact that the spatialization of these conservation units on a metropolitan scale is not associated with a specific sphere of government management nor a political government program, nor even with an urban coalition.

Instead, different political-administrative scales were identified acting in favor of these new spatializations, at different and temporally disconnected levels. This is in line with the interpretation that in the Metropolitan Region of Belem, this recent concern to promote a significant increase in the areas of environmental protection has less to do with a specific type of urban planning and management susceptible to engagements in favor of sustainability, and it is related to the dissemination of a broader agenda that enables interventions in the metropolitan space without necessarily causing visible conflicts between different groups and classes.

It is in this sense that there is a tendency to create spaces for environmental preservation, in a perspective of urban planning and management that permeates different levels of administration. A summary of this movement that is expressed in a normative nature in a set of parks and Conservation Units in the MRB is detailed in Table 1.

The fact that urban and environmental policy have converged since the 1988 Constitution, for increasingly local, or at least subnational, decision-making, is a strong institutional element in favor of this understanding in the Brazilian case. 
Table 1. Metropolitan region of Belem: main environmental protection areas (1988-2018).

\begin{tabular}{|c|c|c|}
\hline Conservation unit & Characteristics & Location in the MRB \\
\hline $\begin{array}{l}\text { Mosqueiro Island } \\
\text { Municipal Park }\end{array}$ & $\begin{array}{l}\text { Formed by a group of islands that seeks to make ecotourism activities feasible, in addition to } \\
\text { protecting the remaining springs, flora and fauna. Created by Municipal Law 1401, of } 1988 \text { and } \\
\text { included in the Master Plan of the Municipality of Belem. }\end{array}$ & $\begin{array}{l}\text { Mosqueiro } \\
\text { District/Municipality of } \\
\text { Belem }\end{array}$ \\
\hline $\begin{array}{l}\text { Gunnar Vingren } \\
\text { Ecological Park }\end{array}$ & $\begin{array}{l}\text { Established in a fragment of primary forest located downtown as a Conservation Unit for full } \\
\text { use. Located between two housing estates and originally formed by } 44 \text { hectares of forest under } \\
\text { the supervision of the Neighborhood Association. Recently, the park had part of its area } \\
\text { suppressed. It currently has } 38 \text { hectares. Created by Municipal Law } 7539 / 1991 \text { and validated as a } \\
\text { Conservation Unit by Federal Law 9985/2000. }\end{array}$ & Municipality of Belem \\
\hline Utinga State Park & $\begin{array}{l}\text { Full Protection Conservation Unit with 1,393 hectares, created by the Government of the State } \\
\text { of Pará. The area was also part of the Special Area for the Preservation of the Environmental } \\
\text { Heritage of the Master Plan of Belem. Ratified by State Decree 1552/1993 and State Decree } \\
265 / 2011 \text {. }\end{array}$ & $\begin{array}{l}\text { Municipalities of Belem } \\
\text { and Ananindeua }\end{array}$ \\
\hline Seringal Park Museum & $\begin{array}{l}\text { Park and museum established as a Conservation Unit of the Ministry of the Environment. The } \\
\text { Conservation Unit is dedicated to leisure, preservation and environmental education, in } \\
\text { addition to preserving regional memory, with reserves of rubber trees cultivated in the Rubber } \\
\text { period. Created by Municipal Law 2231/2006. }\end{array}$ & $\begin{array}{l}\text { Municipality of } \\
\text { Ananindeua }\end{array}$ \\
\hline $\begin{array}{l}\text { Mangal das Garças } \\
\text { Park }\end{array}$ & $\begin{array}{l}\text { Naturalistic park resulting from intervention in an area of } 40,000 \mathrm{~m}^{2} \text { on the banks of the Guamá } \\
\text { River, in downtown Belem. The Park represents the different macroregions of Pará: terra firme } \\
\text { forests, lowland forests and fields. Created by Municipal Law } 8665 \text {, Master Plan of Belem/2008. }\end{array}$ & Municipality of Belém \\
\hline $\begin{array}{l}\text { Amazonian } \\
\text { Metropolis Wildlife } \\
\text { Refuge }\end{array}$ & $\begin{array}{l}\text { Wildlife refuge with } 6367 \text { hectares covering } 6.3 \% \text { of the area of four municipalities of MRB. The } \\
\text { Unit ensures conditions for the existence or reproduction of flora and fauna species, in addition } \\
\text { to maintaining environmental services, with the conservation of } 31 \% \text { of MRB's primary forests. } \\
\text { Created by State Decree } 2211 / 2010 \text {. }\end{array}$ & $\begin{array}{l}\text { Municipalities of } \\
\text { Ananindeua, Benevides, } \\
\text { Marituba and Santa } \\
\text { Izabel do Pará }\end{array}$ \\
\hline $\begin{array}{l}\text { Antonio Danúbio } \\
\text { Environmental Park }\end{array}$ & $\begin{array}{l}\text { Created in an urban void in the central area of the municipality. The area reproduces fruit } \\
\text { plants and is a refuge for small animals. The Park is a multipurpose leisure space established in } \\
\text { the Urban and Environmental Policy of the Municipality through Municipal Law 2472/2011. }\end{array}$ & $\begin{array}{l}\text { Municipality of } \\
\text { Ananindeua }\end{array}$ \\
\hline
\end{tabular}

Source: Institutional information from the Conservation Units. Organized by the author (2020).

From the point of view of decisions, the set of green areas created on a large scale from the 1990s ratifies an orientation disseminated by the political-administrative bodies in making metropolitan development based on the orientation of the use and conservation of the environment, and can be visualized based on three elements that guide the thread of management: 1) the standardization of planning measures with an environmental focus consolidating the materialization of a "greening of the metropolis"; 2) the institutionalization of administrative and environmental instances; 3) the use of a set of practical-sensitive symbols to constitute the desired environmental image, in a kind of "green rebranding".

Regarding the standardization of planning policies and practices with an environmental focus that materialize a "greening of the metropolis", the evidence for the MRB shows that this realization of urban Conservation Units is not associated with large plans or macro-guidelines for green planning. On the contrary, there is much more a set of normative actions and measures in relation to an idealization of urban sustainability that accumulate in different political-administrative spheres in the space production. 
Institutionalization takes place from the installation of political and administrative instances hitherto non-existent, such as the State Secretariat for the Environment and Sustainability of Pará, the Municipal Secretariat for the Environment of Belem and the Municipal Secretariat for the Development of the Environment of Ananindeua. In addition to these executive bodies that guarantee the legitimacy of the actions, the Conservation Units themselves, when created, generate a smaller scale institutional system that aims to manage the conservation areas, such as the Conservation Units Councils.

In terms of using a set of practical-sensitive symbols to express the desired environmental image, there is an attempt to reposition the city's brand, particularly from areas constituted as urbanized nature of which metropolitan parks are an expression. In this case, we are facing a case of "place branding" understood as a reworking of urban marketing aimed at valuing environmental and sustainability issues. Conceptually:

The concept of place branding refers to a variety of practices and tools used by political organizations and local governments to divulge and market an image and set of values associated with their city, region or nation (Andersson \& James, 2018: p. 3438)

It turns out that in the case of MRB, which did not have its urbanization strictly induced to industrialization processes, the "urban greening" expressed in these parks has the clear sense of reaction against the progressive loss of vegetation cover experienced by the city and previously demonstrated and the distance from the "Cidade das Mangueiras" identity. In addition, this attempt at "green rebranding" in the MRB also proves to be a response to the permanent trend of dispersion of the urban fabric of the metropolis over an increasingly broad territory, which leads to related negative effects such as the increase in the vehicle fleet ${ }^{9}$.

In general terms, the instruments that enable the creation of Conservation Units are those made possible by Brazilian urban policy after the promulgation of the Federal Constitution of 1988. One of these instruments is the Municipal Urban Master Plan. In the two largest municipalities that make up the MRB, Belem and Ananindeua, and which have the oldest master plans, the importance of the environmental component in the organization of urban space is visible.

Belem's Master Plan, which has existed since the 1990s, highlights the importance of leisure spaces in the city's sustainable planning policy. The Municipality's Environmental Policy Guidelines highlighted the purpose of "preserving, conserving, recovering and improving the natural, artificial and work environment, taking into account local peculiarities in harmony with economic development, with a view to ensuring the environmental quality conducive to life"

${ }^{9}$ Between 2001 and 2019 the motor vehicle fleet in the two largest cities in the MRB grew exponentially. In Belém, the fleet of 145,000 vehicles in 2001, increased to 469,000 vehicles in 2019. In Ananindeua, 22,000 (2001) to 146,000 (2019). Official data from the Traffic Department of the State of Pará (Detran, 2020). 
(Belém, 1993: p. 1).

Among the main planning instruments established by the Master Plan in Belem, the Special Environmental Preservation Zones (ZEPA) stand out, which were defined as protection areas for water supply sources, areas whose landscape and environmental characteristics were of public interest for preservation and recovery purposes (Belém, 1993). Areas, which ended up corresponding to the preservation area effectively institutionalized in a recent period, as in the case of Utinga Park and Gunnar Vingren Municipal Park (see Table 1).

In the Ananindeua's Master Plan, effective as of 2006, the concern with the environmental issue was expressed via the creation of an administrative structure to address the issue in the management guidelines. This process started with the creation of the Municipal Secretariat for Environmental Development (SEMA), in 2005. In the same year, the municipality instituted its own environmental policy, whose guidelines are the formulation and execution of the Municipal Environmental Policy (Ananindeua, 2006).

In addition to the legal-institutional system that legitimizes the guidelines established within the municipal administration of Ananindeua there is, at the same time, the construction of an urban-environmental spatiality, with the installation of the Antonio Danubio Environmental Park and the Seringal $\mathrm{Mu}$ seum Park, both opened in the 2010s, as detailed in Table 1.

Last, but not least, the participation of Pará's State Government in implementing the environmental policy and conservation areas within the scope of the MRB. Amazonian Metropolis Wildlife Refuge, a haven of wildlife, in an area that is within five municipalities of the MRB, is the largest Conservation Unit in terms of extension in the metropolitan area of Belem and enters the territory of two or more municipalities, as described in Table 1.

Thus, in terms of the metropolitan region, a set of political-administrative initiatives were created acting together, although not in a coordinated manner in the construction of this metropolitan environmental mosaic. The spatiality of this set of policies implemented in the last three decades (1988-2018), is evident from the mapping of metropolitan parks in Belem, according to Figure 5.

In terms of scale, the implementation of a policy for the installation of Conservation Units in amplified scope with the set of metropolitan parks in the $\mathrm{MRB}$, are legitimized by a comprehensive network of relationships that range from the implementation of an urban and environmental agenda with characteristics of international demands, including the institutionalization of Brazilian urban and environmental policy from the 1980s and, finally, effective action, although not necessarily coordinated by subnational actors.

\section{Conclusion}

This paper analyzed the transformations in the production of the metropolitan space in Belem, the largest metropolitan agglomeration in the Amazon region, 


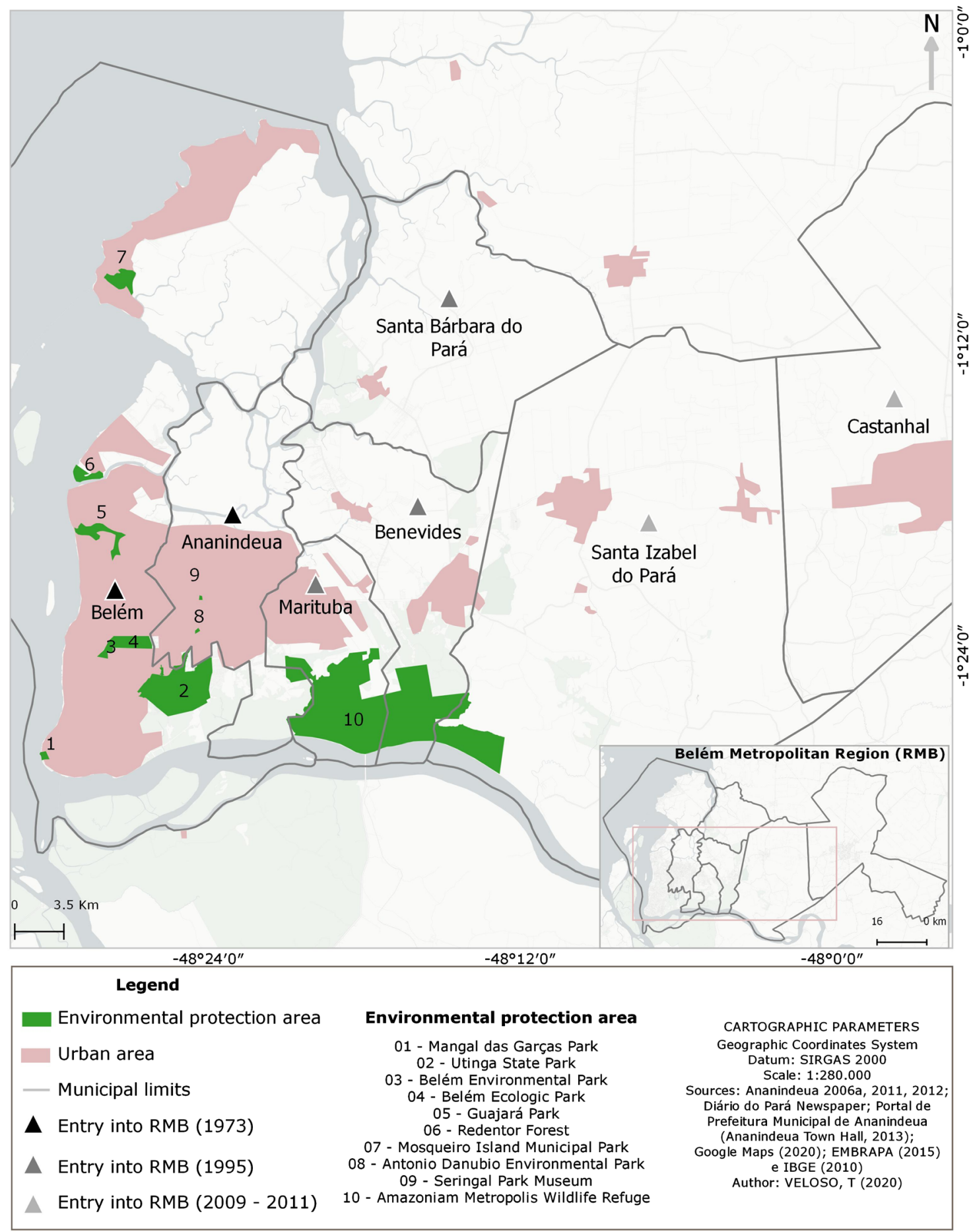

Source: Organized by the author (2020).

Figure 5. Metropolitan Region of Belem: creation of Conservation Units (1988-2018).

based on the concept of "urbanized nature". From the identification of the characteristics of the policies and practices to the establishment of green landscapes at a city scale and later at a metropolitan scale, there was a trend of continuous spreading of the urban fabric, expanding the limits of the metropolitan region 
with repercussions on the characterization of an urban and environmental morphology. The continuous dispersion of the urban-metropolitan fabric caused changes in the metropolis's environmental structure, resulting from the processes of constituting the historical genealogy of this space.

The first observation is about the composition of the production of the urban space of Belém from 1900 to 1960. In that period the city had green areas as an element of beautification and constituted an ideal of tropical modernity and a type of urbanized nature created less by its environmental function than its aesthetic and scenic appeal, such as Rodrigues Alves Zoobotanic Garden and Emílio Goeldi Museum's Zoobotanic Park, derived directly from the urban formulations of the beginning of the twentieth century and associated with an elitist ideal of "urban beautification" based on the city's aesthetic and hygienic ideals, which are progressively lost by the advance of urbanization and the process of metropolization since the 1960 s.

Therefore, from the documentary and iconographic analysis of the city from 1960 , there was a progressive loss of vegetation cover in the central neighborhoods of the city of Belém, as well as in the municipalities that came to make up its metropolitan region from the 1970 s onwards. This loss, verified through satellite images, impacted the image of the city formed over the $20^{\text {th }}$ century around an urbanized nature and synthesized in the "Mango Tree City" idea.

In a more recent period, the analysis of urban and environmental policy identified that the new constitutional regulatory framework influenced the implementation of urban policies, considering the normative framework of the 1988 Constitution. The environmental agenda spread at an international level contributed to a review of urban development patterns on a national and sub-national scale. In this process, urban and environmental planning policies and practices came to play a prominent role.

It is in this recent context that urban planning and development guidelines have been established on a sub-national and local scale. The process of disseminating urban development agendas and programs in the structuring management concepts and practices has particularly influenced urban and environmental policies in the Metropolitan Region of Belém, in which it is possible to recognize the impact of these approaches from its materialization in planning policies and practices that altered urban and metropolitan morphology, especially in the formalization of environmental preservation and conservation areas on a metropolitan scale.

In this sense, we conclude that the most recent metropolitan parks, which have been opened since the 1990s, are legitimized by a more complex web of relationships, such as the increasing pressure for cities with environmental standards on an international level and the demands of the local society. In addition, they make up a spatial materiality of an expanded metropolitan region, with the participation of various agents of society who transform the very morphology of a metropolis with an increasingly dispersed urban fabric. The "Mango Tree City" 
of the $20^{\text {th }}$ century enters the $21^{\text {st }}$ century much more similar to a "Metropolis of Parks".

Finally, the construction of these new materialities in the MRB cannot be dissociated from their content of extreme inequality and permanent unequal access to the right to the city. The location of these new parks in the metropolitan complex, often close to or in the vicinity of high-income residential settlement locations, demonstrates that the inequality surrounding this "green urbanism" continues to be reproduced in the production of the metropolitan space. In the absence of urban and environmental policies with an emphasis on the accessibility of urban and metropolitan transport and housing, a certain "green priority" overlaps these other dimensions that mobilize less conflicts among different groups, classes and views of the city.

\section{Acknowledgements}

I would like to thank the Studies and Research Group of "Urbanodiversidade and Territorial Management at Amazon" (GEOURBAM) for its continued and valuable input and feedback throughout the process of writing and revising this paper. I also thanks to Federal Institute of Education, Science and Technology of Pará for its institutional and financial support for the research. And a Doriene Monteiro Trindade for the flawless translation work accomplished.

\section{Conflicts of Interest}

The author declares no conflicts of interest regarding the publication of this paper.

\section{References}

Ananindeua (2006). Plano Diretor de Ananindeua [Ananindeua máster plan]. Brazil. https://leismunicipais.com.br/plano-diretor-ananindeua-pa

Andersson, I., \& James, L. (2018). Altruism or Entrepreneurialism? The Co-Evolution of Green Place Branding and Policy Tourism in Vaxjo, Sweden. Urban Studies, 55, 3437-3453. https://doi.org/10.1177/0042098017749471

Andrade, K. C., \& Tozi, S. C. (2019). Influências da dispersão metropolitana sobre a cobertura vegetal: Análise do complexo Cidade Nova, em Ananindeua [Influences of Metropolitan Dispersion in Vegetation Cover: Ananalyses of "Cidade Nova" Settlement] In T. V. Santos, T. Júnior, \& S.-C. Cordeiro (Eds.), O urbano e o metropolitano em Belém: (Re)configurações socioespaciais e estratégias de planejamento e gestão [The Urban and the Metropolitan in Belém: Socioespatials (Re)configurations and Strategies of Planning and Management] (pp. 219-236). Rio de Janeiro: Consequência.

Angelo, H., \& Bastos, P. P. M. (2020). O imaginário do esverdeamento urbano: A natureza urbanizada na região alemã do vale do Ruhr [The Urban Green Imaginarium: Urbanized Nature in the German Region of Ruh's Valley]. E-metropólis, No. 41, 8-29. http://emetropolis.net/system/artigos/arquivo_pdfs/000/000/318/original/emetropolis4 1_art-capa.pdf?1594050543

Azevedo, A. N. (2016). Agrande reforma urbana do Rio de Janeiro: Pereira Passos, Rodrigues Alves e as ideias de civilização e progresso [The Great Urban Reform of Rio 
de Janeiro's City: Pereira Passos, Rodrigues Alves and the Ideas of Civilization and Progress]. Rio de Janeiro: Editoria Mauad X.

Belém (1905). Relatório apresentado ao Conselho Municipal de Belém pelo Intendente Senador Antônio José de Lemos [Report Presented for Antonio Lemos Intendentto Council of Belém City] (Volumen 4). Belém do Pará: Archivo da Intendência Municipal.

Belém (1993). Plano diretor urbano do Município de Belém (Belém Urban Master’s Plan). Belém: Prefeitura Municipal de Belém.

https://leismunicipais.com.br/a/pa/b/belem/lei-ordinaria/1993/764/7644/lei-ordinarian-7644-1993-da-nova-redacao-a-dispositivos-vetados-na-lei-7603-de-13-01-93-que-dis poe-sobre-o-plano-diretor-e-da-outras-providencias

Belém (2000). Álbum Histórico da cidade (Belém’s Historic Album). Belém: Secretaria Municipal de Cultura.

Belém (2005). Histórico do Bosque Rodrigues Alves, Jardim Botânico da Amazônia. Belém: Rodrigues Alves Library.

Cavalcanti, A. C. R. (2008). A difusão da agenda urbana das agências multilaterais de desenvolvimento na cidade de Recife [The Diffusion of Urban Agenda in Multilaterals Agencys of Development in Recife's City]. Doctoral Dissertation of Master's Thesis, Recife: Federal University of Pernambuco.

Detran (2020). Estatísticas de Trânsito do do Departamento Estadual do Pará [Statístics from State Traffic Department of Pará]. https://www.detran.pa.gov.br/index_.php

Hoffman, L. (2011). Urban Modeling and Contemporary Technologies of City-Building in China: The Production of Regimes of Green Urbanisms. In A. Roy, \& O. Aihwa (Eds.), Worlding Cities: Asian Experiments and the Art of Being Global (pp. 55-76). Chichester: Blackwell. https://doi.org/10.1002/9781444346800.ch2

IBGE, Instituto Brasileiro de Geografia e Estatística (Brazilian Institute for Estatistical and Geography) (2010). Demographic Census. Brasília.

Lencioni, S. (2008). Concentração e centralização das atividades urbanas: Uma perspectiva multiescalar. Reflexões a partir do caso de São Paulo [Concentration and Centralization of Urban Activities: A Multiescalar View from the São Paulo City]. Revista de Geografia Norte Grande, Natal, No. 39, 7-20. https://doi.org/10.4067/S0718-34022008000100002

Lencioni, S., Vidal-Koppman, S., Hidalgo, R., \& Pereira, P. C. X. (2011). Transformações socioterritoriais nas metrópoles de Buenos Aires, São Paulo e Santiago [Social Transformations in Buenos Aires, São Paulo and Santiago Metropolis]. São Paulo: FAUUSP.

Man and Environment Institute for Amazon IMAZON (2007). Belém Sustentável [Sustaintable Belém]. Belém: IMAZON.

Matos, A. L. N. (2016). Um projetista para a cidade lemista: José Sidrim [A Projector for the "Lemist" City: José Sidrim]. In M. de N. Sarges, \& F. G. Lacerda (Eds.), Belém do Pará: História, cultura e cidade para além dos 400 anos [Belém of Pará: Histpry, Cultura na City beyond 400 Years] (pp. 33-54). Belém: Editora Açaí.

Monte-Mór, R. (2003). Outras Fronteiras: Novas espacialidades na urbanização brasileira [Others Frontiers: New Spatialities in Brazilian Urbanisation]. In L. B. Castriota (Ed.), Urbanização brasileira: Redescobertas [Brazilian Urbanitasion: Rediscovery] (pp. 261-270). Belo Horizonte: Editora C/Arte.

Moreira, E. (1989). Belém e sua expressão geográfica [Belém and It’s Geogaphical Expression. Belém: Cejup.

Rodrigues, E. J. (1998). Banidos da cidade e unidos na condição: Cidade Nova, espeçho da 
segregação social em Belém [Banished from the City, United on Conditions: "Cidade Nova" Settlement as a Mirror of Social Segregation in Belém]. Belém: Universidade Federal do Pará.

Rodrigues, J. E., \& Luz, L. M. (2007). Mapeamento da cobertura vegetal da Área central do município de Belém/PA [Mapping of Vegetal Cover in Belém Central Area]. Brazilian Symposium of Remot Sensing, Florianópolis, 1893-1900.

Sanjad, N. R. (2005). A coruja de minerva: O museuparaense entre o império e a república, 1866-1907 [The Owl of Minerva: The "EmilioGoeldi" Museum between the Impery and the Republic, 1866-1907]. Belém: Museu Paraense Emílio Goeldi.

https://repositorio.museu-goeldi.br/handle/mgoeldi/1230

Santos, M. (2004). A urbanização brasileira [The Brazilian Urbanisation]. São Paulo: Edusp.

Sarges, M. N. (2002). Belém: Riquezas produzindo a Belle-Époque (1870-1912) [Belém: Riches Producing the "Bellé Epoque”. Belém: Paka-Tatu.

Tavares, M. G. C. (2018). Patrimônio e cidade: Uma leitura geográfica da cidade de Belém do Pará [Heritage and City: A Geographic Reader of Belém do Pará]. Geografar: Journal of Post-graduation program of Geography, 13, 162-180.

https://doi.org/10.5380/geografar.v13i1.60269

Trindade Júnior, S. C. C. (1998). A cidade dispersa: Os novos espaços de assentamentos em Belém e a reestruturação metropolitana [Sprawlcity: The New Settlements in Belém and It's Metropolitan Changes]. Doctoral Dissertation of Master's Thesis, São Paulo: São Paulo University.

Vicentini, Y. (2004). Cidade e história na Amazônia [History and City in the Amazon]. Curitiba: Editora da Universidade Federal do Paraná. 